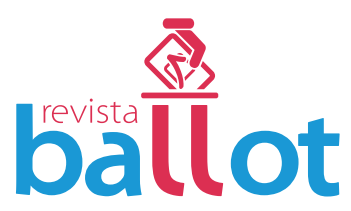

\title{
A Responsabilidade Penal da Pessoa Jurídica no Código Eleitoral Brasileiro - O Artigo 336
}

Jorge Bheron Rocha (Universidade de Coimbra, Portugal)

bheronrocha@gmail.com

Faculdade de Direito - Pátio da Universidade

3004-545 Coimbra 


\title{
Resumo
}

A responsabilização penal da pessoa jurídica é tema candente no Direito moderno, e o presente artigo analisa se as disposiçóes do artigo 339 do Código Eleitoral brasileiro - referentes à imposição de pena de suspensão de atividade eleitoral ao Diretório de Partido Político na sentença que julgar ação penal nos crimes elencados no citado artigo - configuram ou não hipótese de responsabilização criminal de ente coletivo. Inicialmente busca-se realizar uma aproximação histórica da questão na legislação brasileira, e sua contextualização com os mandamentos constitucionais. Em seguida, faz-se um rápido exame dos argumentos favoráveis e contrários à capacidade de a pessoa jurídica delinquir. Ao fim, estuda-se a específica hipótese do dispositivo do Código Eleitoral sob o ponto de vista dogmático.

Palavras-chave: Responsabilidade Penal. Pessoa Jurídica. Código Eleitoral. Constituição

\begin{abstract}
The criminal responsibility of legal entities is current topic in modern law, and this article analyzes if the provisions of Article 336 of the Brazilian Electoral Code - related to the sanction to impose electoral activity suspension to the Political Parties Directories in the sentence it considers criminal action in crimes listed in that Article - configure or not criminal responsibility hypothesis of collective being. Initial the aim is to make a historical approach the issue in Brazilian legislation and its context with the constitutional commandments. And then, it is a quick examination of for and against the ability of the entity offending arguments. At the end, we study the specific case of the Electoral Code of the device under the dogmatic point of view.
\end{abstract}

Keywords: Criminal responsibility. Legal person. Electoral Code. Constitution 


\section{Introdução}

A questão da responsabilização penal da pessoa coletiva, longe de ser uma estéril discussão acadêmica a portas fechadas de gabinetes doutorais sobre filigranas jurídicas sem relevância prática no mundo real, tem forte teor realístico-fático e impacta em campos diversos do viver humano, tendo sido primeiramente admitida no âmbito do Direito Econômico, onde toda a mobilidade de pessoas, capitais, serviços e produtos, que se pode dar de forma lícita e consentânea com as regulares práticas internacionais, não é raro, contudo, que se dê de forma delinquente e nociva às relações socioeconômicas interpessoais, entre pessoas e empresas, interempresariais e, entre os anteriormente citados e os Estados Nacionais. Posteriormente admitida em outras áreas de igual vulnerabilidade ${ }^{1}$ em que, quando expostas ao fenômeno da criminalidade, a repercussão deletéria pode alcançar níveis imperscrutáveis no homem, no espaço e, também, no tempo².

Giram as discussões acerca da responsabilidade penal da pessoa jurídica em torno de dois importantes eixos: de um lado, razóes de cunho político-criminal, uma vez que se identifica, no vórtice da criminalidade de alta escala e de alta complexidade ${ }^{3}$, que os crimes econômicos e ambientais, por exemplo, transfronteiriços por excelência e albergados no seio de pessoas jurídicas, não se submetem às respostas penais tradicionais manejadas pelos ordenamentos jurídicos, o que exige a busca de novas formas de repressão a estes delitos, nomeadamente quando tem como centro principal de atividades os entes coletivos.

A partir desta perspectiva, nasce a necessidade de se aprofundar no estudo do segundo eixo, ligado a estas novas formas de pensar o Direito Penal e à criação de novos - nem tão novos assim - modelos repressivo-penais que abarquem a criminalidade realizada no seio da (a partir da) pessoa jurídica, impondo-se a imprescindibilidade de uma nova dogmática penal e suas categorias de análise do delito - como a ação e a culpa - sem descurar-se do respeito aos princípios erigidos tão duramente ao longo dos séculos e que garantem uma limitação aos poderes do Estado ${ }^{4}$ frente ao regime de liberdades, garantias e direitos.

1. Ensina FARIA COSTA que "as tensões sociais, os conflitos, que se geram através da empresa se alargam para outros campos bem diferenciados (v.g. direito do ambiente, segurança do trabalhador na empresa, fiscalidade) - é indiscutivel que foi a fenomenalidade atinente à criminalidade econômica, suscitada na empresa, que sustentou os primeiros estudos, não só criminológicos, mas também de natureza dogmática". COSTA, Faria. A Responsabilidade Jurídico-penal da Empresa e dos seus órgãos (ou uma Reflexão sobre a Alteridade nas Pessoas Colectivas, à Luz do Direito Penal). Revista Portuguesa de Ciência Criminal. Lisboa: Ano 2 (1992). Pp. 541-542.

2. Que tem, infelizmente, potencial para influir na vida de todas as nações, em razão do constante fluxo de capitais e sua volatilidade, mobilidade de pessoas e mercadorias, bem como em razão da interdependência dos sistemas ecológicos mundiais, haja vista que a natureza não reconhece fronteiras, bandeiras ou idiomas.

3. Alerta Schünemann que o fato de ser a dificuldade ser ainda maior para se responsabilizar penalmente os dirigentes da pessoas colectiva, uma vez que "la división de trabajo conduce a una diferenciación funcional y a una descentralización de los procesos de acción y decisión, a traves de las que el poder de dominio inicial de los órganos directivos se transforma en un «poder de intermediación» y en vez de dominio de la acción existe una función de coordinación, to que, unido a la simultanea descentralización del conocimento, puede conducir como resultado final, incluso, a una «irresponsabilidad organizada». SCHÜNEMANN, Bernd. Responsabilidad penal en el marco de la empresa. Dificultades relativas a la individualización de la imputación. Anuario de Derecho penal y Ciencias penales. VOL. LV. Madrid: 2002. Pp. 16

4. Socorremo-nos novamente em FARIA COSTA para quem "não bastam razóes de política criminal. Exige-se mais. E exige-se, correctamente, em nome da coerência interna e normativa do direito penal" COSTA, Faria. Ob. cit. P. 548 . 


\section{Uma Aproximação Histórica}

A responsabilidade penal da pessoa jurídica, reconhecida e aplicada em várias épocas e em várias sociedades 5 , passou por um acentuado declínio - melhor dizendo, por uma total desacreditação normativa ${ }^{6}$ - a partir do advento das idéias individualistas e antropocentristas disseminadas pelos doutrinadores da Revolução Francesa a partir do fim do século XVIII ${ }^{7}$.

No Brasil, não obstante as Ordenações Afonsinas, Manuelinas e Filipinas - primeiros corpos legislativos a regerem o país enquanto nação colonizada - não prescreverem explicitamente qualquer regência da matéria, mesmo de forma indireta, entende-se que, à semelhança do que ocorria na metrópole portuguesa, às pessoas coletivas eram aplicadas penas pelos juízes "pela mesma forma porque eram aplicadas aos individuos (...) é que era corrente considerar no mesmo pé de igualdade pessoas singulares e coletivas. Apenas em certos casos, o largo arbitrio do juiz dispunba modificava a pena ou a substituia".

$\mathrm{Na}$ legislação penal brasileira do século XIX há registro de que - malgrado estes ventos filosóficos renovadores - não fora completamente excluída a responsabilização penal das corporaçóes, deixando traços evidentes no Código Criminal de $1830^{\circ}$, em vigor no Primeiro Império, e, ainda, no Código Penal de $1890^{10}$, já sob o Regime Republicano. Por sua vez, o Código Penal de 1940 (CP) não trouxe qualquer traço de responsabilização penal dos entes coletivos.

Em 1965 foi promulgada, em 15 de julho, a lei no 4.737, mais conhecida como o Código Eleitoral (CE), sendo publicada em 19 do mesmo mês, com vigência a partir de trinta dias da publicação. $\mathrm{O}$ artigo $336^{11}$ do CE - editado ainda sob a égide da Constituição de 1946, pós-

5. Sobre os antecedentes históricos da responsabilidade penal da pessoa jurídica ver, entre outros: CARVALHO, António Crespo Simões de. A responsabilidade penal das pessoas colectivas. Texto dactilografado. Dissertação de licenciatura apresentada à Faculdade de Direito da Universidade de Coimbra, 1934. FRANCO, Affonso Arinos de Mello. Responsabilidade criminal das pessoas jurídicas. Rio de Janeiro. Gráfica Ypiranga, 1930. BACIGALUPO, Silvina. La Responsabilidad Penal de las Personas Jurídicas. Barcelona: Bosch, 1998.

6. Nesse sentido, a denominada Lei Le Chapelier, de 14 de junho de 1791, cujo art. $1^{\circ}$ expressa "Ĺanéantissement de toutes espèces de corporations des citoyens".

7. Creditada ao sucesso da teoria da ficção de Savigny por uns, e, ao declínio do poder das corporações, por outros (v.g. TORRÃO, Fernando. Societas delinquere potest? : da responsabilidade individual e colectiva nos "crimes de empresa". Coimbra. Almedina. 2010. P. 39).

8. CARVALHO, Ob. cit. Pp. 20-21.

9. "Art. 79. Reconhecer o que for cidadão brazileiro, superior fóra do Imperio, prestando-lhe effectiva obediencia. Penas de prisão por quatro a dezaseis mezes. Art. 80. Se este crime fôr commettido por Corporação, será esta dissolvida; e, se os seus membros se tornarem a reunir debaixo da mesma, ou diversa denominação com a mesma, ou diversas regras."

10. "Art. 103. Reconhecer o cidadão brazileiro algum superior fóra do paiz, prestando-lhe obediencia effectiva:Pena - de prisão cellular por quatro mezes a um anno. Paragrapho unico. Si este crime for commettido por corporação, será esta dissolvida; e, caso os seus membros se tornem a reunir debaixo da mesma, ou diversa denominação, com o mesmo ou diverso regimen: Pena - aos chefes, de prisão cellular por um a seis annos; aos outros membros, por seis mezes a um anno."

11. "Art. 336. Na sentença que julgar ação penal pela infração de qualquer dos artigos. 322, 323, 324, 325, 326,328, 329, 331, 332, 333, 334 e 335, deve o juiz verificar, de acôrdo com o seu livre convencionamento, se diretório local do partido, por qualquer dos seus membros, concorreu para a prática de delito, ou dela se beneficiou conscientemente. Parágrafo único. Nesse caso, imporá o juiz ao diretório responsável pena de suspensão de sua atividade eleitoral por prazo de 6 a 12 meses, agravada até o dôbro nas reincidências." 
-Estado Novo, e da antiga Parte Geral do Código Penal de 1940 - prescreve que, ao verificar que o diretório local do partido político, por qualquer dos seus membros, concorreu para a prática de determinados delitos ${ }^{12}$ ou tendo se beneficiado conscientemente desta prática, deve o juiz impor-lhe a pena de suspensão de sua atividade eleitoral na sentença que julgar a ação penal. Apesar de não ser o primeiro comando legal do qual se tem notícia ${ }^{13}$ no ordenamento jurídico brasileiro que traz consequências especiais às pessoas jurídicas, ligadas às consequências jurídicas dos crimes ali tipificados, certamente o comando inserto no art. 336 do CE traz novidades em sua redação, e, consequentemente, novidades dogmáticas que suscitam dúvidas bastante razoáveis de saber se se trata de uma verdadeira responsabilização penal da pessoa jurídica, ou mera consequência administrativa acessória.

Contudo, antes de adentrarmos na análise dogmática da disposição propriamente dita do art. 336 do CE, cumpre verificar se, sistemicamente, havia no ordenamento jurídico brasileiro a possibilidade de se admitir a responsabilização das pessoas coletivas, o que nos direciona, primeiramente, para os dispositivos constitucionais à época vigentes, a fim de analisar a constitucionalidade da lei, bem como os dispositivos constitucionais atuais, neste caso, para verificar se houve sua recepção na atual ordem constitucional.

Relativamente à Constituição dos Estados Unidos do Brasil, assim ainda denominado, de 18 de Setembro de 1946 - carta esta que retoma o rumo democrático, "propiciando condições para o desenvolvimento do pais" ${ }^{14}$ com alguns importantes acréscimos em relação aos Direitos e Garantias $^{15}$ - trazia nos seus $\$ \$ 29$ e 30 importantes princípios da individualização e da intransmissibilidade da pena ${ }^{16}$, mais intimamente ligados à temática da responsabilização penal da pessoa jurídica. Entretanto, é necessário verificar que tais princípios estão hoje positivados na Carta de 1988, precisamente no artigo 5º, incisos XLV e XLVI ${ }^{17}$, referindo-se,

12. Os arts. 322, 328, 329 e 333, foram revogados pela Lei no 9.504, de 30.9.1997.

13. Anteriormente ao artigo 336 do CE, além das citadas disposições nos Códigos Penais do século XIX, apenas o art. 32 da Lei no 1.802, de 5 de janeiro de 1953 - que define os crimes contra o Estado e a Ordem Política e Social - ainda vigente, trazia um rudimento de responsabilização de um ente coletivo no contexto do direito criminal, mas, entretanto, renunciava ao carácter penal da responsabilidade e, por conseguinte, da sanção, ao remeter a tramitação do processo competente de apuração para o Ministério do Trabalho, Indústria e Comércio: "Art. 32. O sindicato, associação de grau superior ou associação profissional cujos dirigentes com apoio, aquiescência ou sem objeção da maioria dos seus associados, incorrerem em dispositivo desta lei, ou, por qualquer forma, exercerem ou deixarem exercer, dentro do âmbito sindical, atividade subversiva, terão cassadas suas cartas de reconhecimento ou cancelado o respectivo registro, observando sempre o disposto no artigo 141, §12, da Constituição".

14. SILVA, Jose Afonso da. Curso de Direito Constitucional Positivo. $25^{\circ}$ Ed. Maleiros Editora. São Paulo: 2005. P. 85

15. O rol de direitos fundamentais retoma o que existia na Constituição de1934, com alguns importantes acréscimos, como o do princípio da inafastabilidade de jurisdição, e supressões relevantes, como a exclusão da pena de morte, do banimento e do confisco. PAULO, Vicente; ALEXANDRINO, Marcelo. Direito Constitucional Descomplicado, 7. Ed. Método. São Paulo: 2011. P. 30.

16. "Art. 141 - A Constituição assegura aos brasileiros e aos estrangeiros residentes no País a inviolabilidade dos direitos concernentes à vida, à liberdade, a segurança individual è propriedade, nos termos seguintes: $\$ 29$ - A lei penal regulará a individualização da pena e só retroagirá quando beneficiar o réu. $\ 30$ - Nenhuma pena passará da pessoa do delinqüente."

17. “Art. $5^{\circ}$ (...) XLV - nenbuma pena passará da pessoa do condenado, podendo a obrigação de reparar o dano e a decretação do perdimento de bens ser, nos termos da lei, estendidas aos sucessores e contra eles executadas, até o limite do valor do patrimônio transferido; XLVI - a lei regulará a individualização da pena e adotará, entre outras, as seguintes: a) privação ou restrição da liberdade; b) perda de bens; c) multa; d) prestação social alternativa; e) suspensão ou interdição de direitos; " 
respectivamente, à intransmissibilidade da pena e à sua individualização e tais disposições não impediram - ao lado do princípio da culpabilidade, inciso LVII - que o constituinte originário inscrevesse a responsabilidade penal da pessoa jurídica de forma expressa no art. $225, \S 3^{\circ}$ e, de forma tácita ou velada, no art. $173, \S 5^{\circ}$.

\section{Pessoa Jurídica: (In)Capacidade de Delinquir}

É importante ressaltar que grande setor da doutrina brasileira, e também no mundo, argumenta, resumidamente, que uma eventual responsabilidade penal da pessoa jurídica não se alinha ao princípio da culpabilidade, pois apenas as pessoas humanas têm imanente um juízo de reprovabilidade. Consequentemente, os entes coletivos não teriam capacidade de culpa, o que torna inviável observar o princípio da individualização da pena, em sua fase judicial, uma vez que faltaria ao julgador esse elemento fundamental para a escolha da qualidade da pena e a fixação do quantum. Ademais, ao se condenar a pessoa jurídica restaria quebrantado o princípio da pessoalidade da pena ${ }^{18}$, pelo fato de que, ao condenar o ente moral, estar-se-ia atingindo, inexoravelmente, as pessoas individuais que a integram, seja na condição de sócios ou trabalhadores, e, ainda, quiçá os consumidores e fornecedores, que poderiam sofrer os efeitos deletérios da sanção, nomeadamente a pena de multa ${ }^{19}$.

Alinham-se, ainda, a estes argumentos, a incapacidade de ação ou de omissão típicas da pessoa jurídica, unicamente perpetráveis por intermédio de uma pessoa física ${ }^{20}$ e a incapacidade mesmo de pena, pois se não seria possível cumprir as finalidades - seja retributiva ou de

18. Para PUIG o argumento da prevenção geral não justifica a extensão da responsabilidade penal até a pessoa colectiva, pois sofreria forte limitação no princípio da pessoalidade da pena, fundada no respeito à dignidade humana presente no Estado Democrático de Direito. PUIG, Santiago Mir. Derecho Penal. Parte General. 9a Edición. Barcelona: Editorial Reppertor, 2011. Pp. 189 e ss.

19. A desaprovação jurídico-penal da pessoa coletiva através da pena alcançaria em maior ou menor medida a todas as pessoas que estivessem ligadas a ela (administradores, diretores, trabalhadores), o que seria injusto para aqueles que não tivessem relação com o delito cometido. A responsabilidade penal da pessoa colectiva colocaria no "mesmo saco" os justos e os pecadores, pois, ao imputar o delito à pessoa coletiva, culparia a todos os sócios pelos delitos cometidos apenas por um ou alguns deles. PUIG, Santiago Mir. Sobre la responsabilidade penal de las personas juridicas. Luziada n 3, Lisboa: Universidade de Lisboa, 2005, Pp. 155 e ss.

20. As pessoa jurídicas são incapazes de ação, pois só atuam por intermédio de seus órgãos, e tal seria a razão de não poderem ser castigadas por si mesmas. JESCHECK, Hans-Heinrich. Thomas Weigend. Tratado de Derecho Penal. Parte General. Tradución de Miguel Olmedo Cardenete. Quinta Edición. Comares Editorial. Corregida y Ampliada. P. 243. As pessoas colectivas não podem delinquir, uma vez que lhe falta uma substância psicoespiritual, o que thes impede de se manifestarem por si mesmas. Ensina o autor que apenas os seres humanos podem atuar com eficácia pelas empresas, por esta razão a punição deve incidir sobre aqueles e não sobre estas. ROXIN, Claus. Derecho Penal. Parte General, Tomo I. Fundamentos, La Estructura de la Teroria del Delito (Traducción y notas: Diego Manuel Luzón Peña, Miguel Diaz y Garcia Conlledo, Javier de Vicente Remesal). Civitas. 1997. P. 256. Falta à pessoa colectiva uma substância psíquico-espiritual, na dogmática tradicional, não se atribui a pessoa colectiva uma capacidade de ação, de culpa, de tipicidade ou mesmo de pena. ZAFFARONI, Eugenio Raúl. Alejandro Alagia; Alejandro Slokar. Derecho Penal. Parte General. Buenos Aires, Argentina. Segunda Edición. 2002. Pp. 426 e ss. É evidente que uma pessoa colectiva não pode realizar nenhum dos elementos que exige a dogmática tradicional do direito penal, pois a única conduta possível para a realização do delito é a conduta humana, e, não sendo a pessoa colectiva capaz de atuar por si mesma, não é capaz de aportar para a ação os elementos subjetivos e pessoais do delito. PUIG, Santiago Mir. Ob. cit. 
prevenção geral ou especial - por faltar uma capacidade de reproche ético ${ }^{21}$. Elenca-se, ainda, a impossibilidade de se aplicar uma pena de prisão ${ }^{22}$.

Não obstante estes argumentos, há vozes que, mesmo contrárias à incriminação das pessoas jurídicas, reconhecem a possibilidade de se lhes atribuir a responsabilidade penal traduzida em mera escolha do legislador - no caso o constituinte originário - desde que não haja respeito aos límites ônticos, que poderia, assim, realizar uma "equiparação" da tomada de decisão dos órgãos da pessoa jurídica com a tomada de decisão da pessoa humana, abrindo-se a porta para a aceitação de uma ação e de uma culpa próprias da corporação $0^{23}$.

Há se ter em mente, que a pessoa jurídica não se trata de uma entidade completamente diáfana no mundo jurídico ${ }^{24}$, mas de um ente a que o sistema jurídico atribui a capacidade de firmar contratos e ser sujeito de obrigaçóes, os quais, eventualmente, pode descumpri-los, inclusive com afronta à norma penal. Acrescente-se que há normas jurídicas que se dirigem unicamente aos entes coletivos, e não às pessoas físicas, sendo, portanto, seu descumprimento apenas àqueles atribuível ${ }^{25}$.

Os partidos políticos adquirirem personalidade jurídica na forma da lei civil ${ }^{26}$, constituindo-se pessoas jurídicas de Direito privado ${ }^{27}$, são "uma forma de agremiação de um grupo social

21. Para MIR PUIG a maior gravidade da pena se dá em termos simbólicos por razão da desaprovação social mais elevada que representa uma condenação criminal, e que só se justifica a imposição de uma pena ao culpado pelo fato, pois apenas o culpado pode reprovar-se e perceber que é merecedor daquela sanção, quedando-se a pessoa jurídica "incapaz de actuar por sí misma, carente de consciência y de cualquier sentido de responsabilidad". Aduz que, sendo a pessoa colectiva uma pura criação jurídica, não pode sofrer uma reprovação por um fato sobre o qual não poderia ter decidido, nem realizado e nem evitado PUIG, Santiago Mir. Ob. cit. P. 159.

22. Assim, apenas as pessoas físicas podem ser sujeito adequado de um juízo de desaprovação ético-social que representa a pena, não existindo lógica em aplicar uma pena privativa de liberdade ou privativa de direitos a uma pessoa jurídica. PUIG, Santiago Mir. Derecho Penal (...) Pp. 189 e ss.

\section{ZAFFARONI, Eugenio Raúl. Ob. cit. Pp. 426 e ss.}

24. Lembra FIGUEIREDO DIAS que a ação e a culpa, enquanto categorias penais, foram erigidas em consonância com a ideia de um ser livre, entranhado de valores susceptíveis de apuração jurídica, ou seja, as categorias da ação e da culpa são pensadas sob o ponto de vista do ser humano. Entretanto, uma vez reconhecida a necessidade e conveniência imperiosas no âmbito político criminal de reconhecer a responsabilidade penal da pessoa colectiva, não podem os conceitos dogmáticos de culpa e ação sofrerem uma "ontificação e autonomização" tais que os constituam obstáculo intransponível à conformação da realidade normativa à realidade social. Assim, sendo as categorias da culpa e da ação pensadas sob o ponto de vista do "ser livre", a mesma liberdade deve ser verificada nas pessoas colectivas, pois se constituem "obras de liberdade" ou realizaçóes do ser livre, "pelo que parece aceitável que em certos domínios especiais e bem delimitados, ao homem individual podem substituir-se, como centro ético-sociais de imputação jurídico-penal, objectiva e subjectiva, as suas obras ou realizaçōes colectivas, e assim, as pessoas colectivas, associaçōes, agrupamentos ou corporações em que o ser livre se exprime" DIAS, Jorge de Figueiredo. Direito Penal. Parte Geral. Tomo I. $2^{\circ}$ Edição, Questóes Fundamentais. A doutrina geral do crime. Coimbra Editora, 2007. P.298

25. Ensina LISZT "Que uma corporação commetta crimes é juridicamente possível; porquanto, de um lado, os requisitos de sua capacidade de facto em materia de direito penal não são fundamentalmente diversos dos que o direito civil exige ou dos que exige o direito publico (circumstancia esta que de ordinário não é notada). Quem pôde celebrar contractos, pôde tambem celebrar contractos usurários ou eivados de burla, ou não cumprir os contractos de fornecimento que tenha concluído”. LISZT, Franz von. Tratado de Direito Penal Allemão. Tradução da última edição e commentado por José Hygino Duarte Pereira, Tomo I, Rio de Janeiro: F. Briguiet \& C. Editores, 1899. P. 190

26. Art. 17, §2 da Constituição da República Federativa do Brasil.

27. Art. 44, V, Código Civil brasileiro. 
que se propóe organizar, coordenar e instrumentalizar a vontade popular com o fim de assumir o poder para realizar seu programa de governo" ${ }^{28}$, mas não fazem parte do Estado, enquanto estrutura organizacional, nem são entidades de mercado, pois não buscam fins lucrativos. Os partidos podem constituir diretórios - um órgão de administração de um partido político - em níveis nacional, estadual e municipal, cada um com um cadastro nacional de pessoa jurídica diverso, "cadastrados exclusivamente na condição de estabelecimento matriz"29.

O partido político, bem como as demais pessoas jurídicas, age por intermédio de seus órgãos e representantes, e as ações destes devem ser àquele imputadas, uma vez que a sua existência é plenamente dependente da própria existência de seus representantes ${ }^{30}$. Não se trata de uma escolha da pessoa jurídica o ter representantes - dentre outras opçóes possíveis - se trata de uma relação que "funda-se e encontra a sua razão de ser em uma relação interna com o «outro»". É da essência mesma da pessoa jurídica esta Relatio in Altero, e "não se trata de uma relação para com o outro, mas antes de uma relação em que o "outro» (o órgão ou representante da pessoa coletiva) está necessariamente presente" 31 .

No campo das ideologias e dos movimentos políticos ocorre uma certa inversão de ordens, aqui, não é apenas a entidade coletiva que necessita da (e se funda na) relação com o outro - o representante - para nascer juridicamente para o mundo, também "o individuo isolado não tem, politicamente, nenhuma existência real, não podendo exercer influência real sobre a formação da vontade do Estado" ${ }^{32}$. O ser humano individual - sozinho - sequer pode se candidatar se não fizer parte de um partido político, sequer pode votar em alguém, se este igualmente não compor os quadros de uma agremiação política.

A ideia de imputação da ação de uma pessoa à outra não é instituto desconhecido da dogmática penal moderna, ao revés, é comum nos casos de autoria mediata ou de coautoria ${ }^{33}$, e, ainda, a responsabilização penal das pessoas físicas sem que a elas possa ser reconhecida qualquer ação am sentido estrito, como, por exemplo, nos crimes omissivos ${ }^{34}$. Por outro lado, as configuraçóes escolhidas pelo legislador para dar feição a determinados institutos penais do ordenamento jurídico, passam pela análise dos valores culturais da comunidade, que podem ter sentidos inversos, como, por exemplo, retirar ao menor a capacidade de exercer um

28. SILVA, José Afonso da. Ob. cit. P. 394.

29. Instrução Normativa da Receita Federal do Brasil n 1.470, de 30 de maio de 2014.

30. Diferentemente do que ocorre com outros representados, como, por exemplo, com as crianças. que, embora sozinhas e eventualmente isoladas (casos de desaparecimento nas selvas), continuam a ser titulares de deveres e direitos, sem necessidade uma entreposta pessoa para tal. $\mathrm{O}$ mesmo não ocorre com uma pessoa colectiva, que sequer se constitui, ou se relaciona, sem a presença de uma pessoa física.

31. COSTA, Faria. Ob. Cit. P.556.

32. Kelsen, Hans. A Democracia. Ed. Martins Fontes. São Paulo: 2000. P. 39

33. "(...) el principio de imputación recíproca de las distintas contribuiciones. Según este principio, todo lo que haga cada un de los coautores es imputable (es extencible) a todos los demás. Sólo así puede considerarse a cada autor como autor de la totalidad. Para que esta imputación recíproca pueda tener lugar es preciso el mutuo acuerdo, que convierte en partes de un plan global unitário las distintas contribuiciones". PUIG, Santiago Mir. Derecho Penal. Parte General. 9a Edición. Editorial Reppertor. Barcelona 2011. Pág. 400.

34. TIEDEMANN, Klaus. Responsabilidad penal de personas jurídicas y empresas en derecho comparado. Coleção Temas Atuais de Direito Criminal. Cood. Luiz Flávio Gomes. São Paulo. Editora RT. 1999. P.31 
juízo de valor sobre a ação que poderia perfeitamente servir de sustentáculo a censura ético-jurídica, ou, na hipótese da pessoa jurídica, expandir essa normatividade para abranger o agir penalmente relevante, fazendo dela um centro de imputação ${ }^{35}$.

Outrossim, a falta e a culpa na organização legitima a responsabilização penal da pessoa coletiva, permitindo a imputação da conduta individual dos dirigentes à empresa, em razão de esta se encontrar obrigada a adotar medidas de organização, precaução e vigilância de forma a evitar a prática de crimes pelos seus membros e órgãos. A organização correta da pessoa jurídica é um dever dela mesma, e não unicamente das pessoas físicas, configura-se importante não apenas a ação física, nestas hipóteses "es la violación de las medidas e las expectaticas normativas la que importa para imputar um resultado nocivo a un autor (persona física o moral)"36.

Assim, diante da perpetração de um crime resultante de uma cultura corporativa delitiva (atitudes, políticas, regras ou práticas internas da corporação), a teoria da culpa na organização defende que os delitos cometidos pelas pessoas singulares devem ser imputados à própria pessoa coletiva, não sendo unicamente um "critério que legitima la punición de la agrupación, sino que reemplaza o constituye la culpabilidade misma" ${ }^{\prime 3}$, haja vista que estas não adotaram as medidas necessárias à observância dos deveres de controlo e precaução, aptos à garantir o desenvolvimento regular e legal de suas actividades ${ }^{38}$.

$\mathrm{Na}$ realidade da vida social, existe a discursividade da responsabilidade de uma empresa pela poluição do ar ou pela colocação defeituosa de um produto no mercado, por exemplo, sendo, portanto, possível às pessoas jurídicas serem destinatárias de normas éticas e também do reproche ético, pois se encontram em posição de violar estas normas. Aos olhos da sociedade, a culpabilidade da empresa está completamente reconhecida, havendo aqui uma reprovação ético-moral da comunidade em relação à conduta delitiva imputada à corporação ${ }^{39}$. Trata-se, assim, de uma culpabilidade social, ou seja, da existência do reconhecimento social da culpabilidade da entidade coletiva em determinadas hipóteses - como nos casos de vazamento de petróleo que polui um rio ou corrupção em licitação - que leva a uma reprovação ético-moral relativamente àquela, possibilitando que se admita a "culpabilidad moral o social de

\section{A chamada Teoria da Racionalidade dos Lugares Inversos de FARIA COSTA. Ob.cit.}

\section{TIEDEMANN, Klaus. Ob.cit. Pp.29 e ss.}

\section{Idem, ibidem. P.31}

38. Às teorias que buscam enquadrar na nova dogmática uma ação própria das organizações, ROXIN responde não se pode imputar nem ação nem culpabilidade alheias (dos órgãos ou administradores) como próprias da pessoa coletiva. À teoria da culpa na organização, ROXIN enfrenta afirmando que, tal como ocorre com a ação, também a falta de organização ou organização defeituosa só pode ser realizada pelos seus diretores, portanto, condutas de pessoas individuais. ROXIN, Claus. Ob.cit. P.256,. Entretanto, as pessoa coletivas, como pessoas sociais, são um sistema autopoiético organizativo, caracterizado pela autonomia, autoadministração, autocondução e auto-organização, independente dos membros concretos, cuja condição já não se constitui em relação com os indivíduos concretos ou características abstratas, essa condição remete-se às estruturas internas da empresa, por isso podem ser continuamente trocados e o ente coletivo conservar sua identidade. Neste sentido ver: DÍEZ, Carlos Gómez-Jara. El modelo constructivista de autorresponsabilidad penal empresarial. In Modelos de autorresponsabilidad penal empresarial propuestas contemporáneas. Madrid: 2006, Pp. 93-162; e TEUBNER, Gunther. O direito como sistema autopoiético. Tradução e prefácio de José Engracia Antunes. Lisboa: Fundação Calouste Gulbenkian, 1993.

39. TIEDEMANN, Klaus. Ob.cit. P. 31 
la agrypamiento" 40 e, consequentemente, redundando na ideia de retribuição da punição penal aplicável à pessoa coletiva.

Não seria o caso, portanto, de se reconhecer qualquer responsabilidade penal objetiva ${ }^{41}$, tão questionada pelos opositores da possibilidade de incriminação do ente coletivo, mas de construir uma culpabilidade própria do agrupamento, a partir de sua natureza e amoldada à suas características.

Ora, a pessoa jurídica pode figurar no polo passivo da relação material penal, como vítima, nomeadamente - se deve destacar - nos crimes contra a honra, conforme já amplamente reconhecido na jurisprudência ${ }^{42}$ e na doutrina. Em sendo sua honra um patrimônio imaterial passível de diminuição através de um ato ilícito, nada obsta que também o seja através de um ato lícito - a pena. Assim, sendo a pessoa coletiva titular de bens jurídicos próprios e diferenciados das demais pessoas (individuais ou outras coletivas), as restriçóes advindas da sanção penal, que tem fundamento "na realização dos efeitos socialmente úteis que a punição desencadeia" ${ }^{\prime 3}$, recairão sobre estes bens que lhe pertencem, e, cumprindo com a função da pena na ambiência de um Estado de Direito Democrático, cujos princípios estruturantes só conseguem alinhar-se a uma sanção que tenha viés predominantemente ressocializador e seja apta a proteger os bens jurídicos relevantes.

Ademais, efeitos colaterais da pena poderão ser sentidos por pessoas - individuais ou coletivas - que com o ente jurídico infrator mantenha relaçóes diretas, em decorrência do cumprimento de uma sanção penal, como a pena de multa ou a privação do direito a subsídios, subvençóes ou incentivos. De fato, pode-se sentir uma diminuição no pagamento do pró-labore aos sócios, na participação dos lucros dos diretores, dispensa de empregados, variação de preços ao consumidor, ou na diminuição da demanda em relação aos fornecedores. Contudo, este cenário em nada destoa do que ocorre com a pessoa física infratora, uma vez que, com a privação da liberdade, sofrem parentes e amigos sem a presença do ente querido, ou, ainda, em decorrência da obrigação de pagar uma multa penal, tem que se desfazer de bens, demitir empregado doméstico a fim de reequilibrar o orçamento familiar, diminuir a demanda por produtos e serviços através da alteração do padrão de vida da família (corte de despesas com TV a cabo, viagens, etc.). São efeitos secundários, como dito, e não se caracterizam como transcendência da pena ${ }^{44}$.

40. Idem, ibidem. P. 32

41. NUCCI destaque que "ainda que não tivesse vontade própria, passivel de reconbecimento através do dolo e da culpa, é preciso destacar existirem casos de responsabilidade objetiva, no direito penal, inclusive de pessoa fisica, como se dá no contexto da embriaguez voluntária, mas não preordenada". NUCCI, Guilherme de Souza. Manual de Direito Penal: parte geral; parte especial. 4. ed. São Paulo: Editora RT, 2008. P. 165.

42. STF - RHC 83091 / DF Min. Marco Aurélio. TSE - RP - Representação No 14472 - São Paulo/Sp Min. Carlos Mário da Silva Velloso

43. MIRANDA RODRIGUES, Anabela. A determinação da medida da pena privativa de liberdade : os critérios da culpa e da prevenção. Coimbra: Coimbra Editora, 2014, p. 155.

44. Em sentido formal, a pena, com exceção daquelas de caráter pecuniário, não possa ultrapassar, transcender a pessoa do condenado, sabemos que, informalmente, não somente aquele que praticou a infração sofre os rigores da lei penal, como também todos aqueles que o cercam. A família do condenado, geralmente, perde aquele que trazia o sustento para casa; os filhos deixam de ter contato com os pais; seus parentes sofrem o efeito estigmatizante da condenação criminal e passam a ser tratados, também, como criminosos etc. GRECO, Rogério. Curso de Direito penal: parte geral. V.1. 12. ed. rev. ampl. e atual. Impetus, Rio de Janeiro: 2010., P.77 
Também é levantado o argumento de que a Constituição de 1988 autorizou, de forma expressa e taxativa, a responsabilidade penal da pessoa coletiva apenas no que respeita aos crimes ambientais, sendo vedada em qualquer outra hipótese. Tal argumento não tem como resistir. A uma, porque todas as questões político-criminais que fundamentam a escolha do constituinte originário pela instituição da responsabilidade penal da pessoa jurídica no âmbito da criminalidade ambiental podem ser suscitadas em outros espaços de criminalidade, como na saúde pública, ordem econômica e financeira, ou, ainda, nas relaçóes de consumo. A duas, porque uma vez construídos os instrumentos dogmáticos que possibilitam a apuração da responsabilização penal da pessoa jurídica - ilícitos-típicos, culpabilidade, sistema de imputação, bem como o sistema de penas - não há óbice para que não sejam aplicados a outras hipóteses que reclamem a resposta estatal à criminalidade das coletividades. Por derradeiro, não se pode entender que as disposições constitucionais dos arts. $225, \$ 3^{\circ}$ e $173, \S 5^{\circ}$ são uma espécie de "autorização" extraordinária e taxativa ao legislador ordinário para que este possa legislar nesta seara, mas, sim, determinações diretas para que, naqueles pontos, seja operacionalizada esta responsabilidade penal da pessoa jurídica, uma vez que não seria sequer necessária esta previsão constitucional para a existência - constitucionalmente assegurada - de uma legislação penal neste sentido ${ }^{45}$.

Dizendo de outra forma: a previsão expressa do art. $225, \$ 3^{\circ}$ e a tácita do art. $173, \S 5^{\circ}$, não se configuram uma exceção constitucional aos princípios também constitucionais da personalidade (individualização, culpabilidade, intransmissibilidade) da pena, autorização expressa - balizada e limitada - plasmando um rol taxativo das hipóteses de responsabilidade penal da pessoa coletiva no ordenamento jurídico brasileiro, senão em rol meramente exemplificativo, podendo o legislador infraconstitucional prever outras hipóteses, sem abrir mão, é bom que se ressalte, da observância dos demais princípios constitucionais diretores do Direito Penal, nomeadamente o da dignidade penal, subsidiariedade, ultima ratio ${ }^{46}$, fragmentariedade, intervenção mínima.

Assentadas as bases dogmáticas e verificados os fundamentos político-criminais pertinentes ao caso, cabe ao legislador optar pela solução no Direito Penal que compreenda ser a melhor escolha para a proteção do bem jurídico, podendo esta escolha se traduzir na responsabilização penal do ente coletivo. Afinal, o próprio constituinte originário atribuiu competência ao legislador infraconstitucional para legislar sobre Direito Penal - art. 22, I, observando-se, como já dito, em relação à responsabilidade penal da pessoa coletiva - como de resto em todos os demais casos que envolvem o contexto jurídico-penal - os demais princípios constitucionais.

45. Tal como não existe disposição constitucional em outros ordenamentos jurídicos para a responsabilização penal da pessoa coletivo, malgrado a legislação infraconstitucional a preveja, como, por exemplo, em Portugal, onde está presente explicitamente o princípio intransmissibilidade da responsabilidade penal ("artigo 30.....) 3. A responsabilidade penal é insusceptível de transmissão").

46. Neste ponto, ficamos com SCHÜNEMANN, para quem o direito administrativo, em várias searas, não se pode dispensar o controle do direito penal, aliás, o inverso por de ser verdade, no sentido que, em algumas áreas, o direito penal consegue dispensar o direito administrativo, de forma que "não é sustentável a tese de que o emprego do direito penal é em princípio subsidiário e posterior ao controle por autoridades da administração" e "deve-se analisar o bem jurídico protegido, os caminhos que levam a sua lesão em determinados contextos históricosocial, bem como os recursos para a sua proteção" SCHÜNEMANN, Bernd. O Direito Penal é a Ultima Ratio da Proteção de Bens Jurídicos. Sobre os Limites Invioláveis do Direito Penal em um Estado de Direito Liberal. Revista Brasileira de Ciências Criminais. São Paulo, n.53, 2005. Pp.. 22 e 23. 
Assim, pelas razões expostas acima, resta saber se a previsão do art. 336 do CE relativamente à pessoa coletiva se trata de hipótese de responsabilização penal ou outra forma de responsabilização. Caso seja penal, pela igual razão que os princípios constitucionais da individualização, intranscendência e pessoalidade da pena e de culpabilidade não obstaculizam a responsabilização penal da pessoa coletiva em relação aos crimes destinados à proteção ao meio ambiente cultural, artificial e natural, também estes mesmos princípios - alguns inscritos expressamente na Constituição de 1946 - não poderiam impedir o legislador infraconstitucional de 1965 a incriminar a pessoa jurídica no contexto dos crimes eleitorais. Em consonância com o apotegma ubi eadem legis ratio ibi eadem dispositivo.

\section{4. $\mathrm{O}$ art 336 do CE se trata de hipótese de responsabilidade penal da pessoa jurídica?}

Tem-se respondido negativamente a este questionamento usando desde argumentos superficiais, como o de que "a única possibilidade autorizada pela Constituição para punição da pessoa jurídica é por crime ambiental", passando pelo argumento de que se trata meramente de pena de caráter administrativo e não criminal, pois a suspensão se restringe à atividade eleitoral, mantendo os serviços administrativos, o que descuraria o caráter penal da sanção, e, por conseguinte, da responsabilidade inscrita no citado artigo, ou seja, a norma inscrita no artigo 336 do CE seria norma de responsabilidade administrativa da pessoa jurídica diretório do partido ${ }^{47}$.

Por outro lado, também há entendimento de que "a admissão da regra da responsabilidade penal dos partidos políticos tornou-se (...) de rarefeita sustentação" em razão da disposição advinda posteriormente no art. $90 . \$ 1^{\circ}$ da Lei $n^{\circ}$ 9.504/97, em que, supostamente "o legislador, em norma posterior, tratou de individualizar a responsabilidade penal, adequando-a ao princípio da culpabilidade", admitindo a incriminação tão-somente em relação às pessoas individuais.

Ora, os argumentos não se sustentam, desde a malfadada taxatividade de a responsabilidade penal da pessoa jurídica se dar apenas no contexto dos crimes ambientais - já rebatida supra - pelas seguintes razóes: primeiramente, porque a norma que prevê a responsabilidade da pessoa jurídica está inserida em contexto puramente criminal - análise literal e tópica; em segundo lugar, porque é expressa em se reportar à atuação própria da pessoa jurídica diretório local, ainda que por intermédio de seus representantes, membros do diretório; em terceiro lugar, porque a responsabilidade é apurada em processo penal; em quarto lugar, porque o art. 336 "prescreve uma sanção a atingir o diretório do partido político a ser decretada na sentença penal condenatória ${ }^{48 "}$ ", a sanção é proferida em sentença com juízo de certeza (após a verificação do juiz, por livre convencimento motivado, na sentença); em quinto lugar, a suspensão da atividade eleitoral é uma sanção restritiva de direito - dentre as muitas que podem ser previstas, conforme expressa disposição constitucional - plenamente adequada a ser imposta à pessoa jurídica da hipótese; e, por último, se trata de sanção com moldura penal, que, para a fixação, levará em consideração as circunstância do art. 59 do CP, no que couber, e do parágrafo único

47. COSTA, Tito, Crimes Eleitorais e Processo Penal Eleitoral. Editora Juarez de Oliveira, São Paulo: 2002. Pp. 110 e ss.

48. GOMES, Suzana de Camargo. Crimes Eleitorais. 2a Edição. Editora: Revista dos Tribunais. São Paulo: 2006. P. 215 
do art. 336 do CE - a reincidência, em obediência à individualização da pena, ou seja, em cada caso haverá uma pena individualizada correspondente, em razão do delito e de suas circunstâncias.

Interessante, ressalte-se, verificar a questão da alegação de posterior revogação do art. 336 do CE pelo art. $90 . \$ 1^{\circ}$ da lei $n^{\circ} 9.504 / 97$, com o entendimento de que, através de uma “interpretação sistêmica, não podemos conviver com a antinomia (...) a opção trilha pela revogação do artigo que à regra da responsabilidade penal da pessoa jurídica"49.

Ora, a Lei no 9.504/97 - que estabelece normas para as eleições - determina textual e expressamente, no citado $₫ 1^{\circ}$ do art. 90 , que a questão de que "respondem penalmente pelos partidos e coligações os seus representantes legais" é aplicado apenas "para os efeitos desta Lei", a saber, a própria Lei no 9.504/97. Não há que tentar argumentar, sem cair num argumento sofista, que esta determinação deve ser aplicada ao $\mathrm{CE}$, pois não é isso que expressamente dispóe. Ao revés, a citada Lei $\mathrm{n}^{\circ}$ 9.504/97 determina na verdade que as disposições do Código Eleitoral devem a ela ser aplicadas, especificamente o disposto nos arts. 287 e 355 a 364.

Ficamos ao lado dos autores que sustentam ser "o art. 336 da presente lei prevê punição criminal para os partidos politicos" ${ }^{50}$ e que "nasceu avançado para a época" e, ainda hodiernamente esta matéria "em outras áreas conta, ainda hoje, com uma resistência quanto à sua aceitação"

\section{A Dogmática do Art. 336 do CE}

Analisando o art. 336 do CE, este informa que: 1) a conduta tenha se dado por qualquer membro do diretório; 2) o diretório local do partido tenha concorrido para a prática de delito ou dela se tenha beneficiado; 3 ) a pena será dada na sentença da ação penal; 4) a sanção a ser imposta é a de suspensão da atividade eleitoral do diretório local.

Inicialmente impende dizer que o diretório do partido deve agir por qualquer de seus membros, não qualquer membro do partido, mas, nos termos do artigo 336 do $\mathrm{CE}$ a conduta deve se dar por intermédio de algum dos membros do diretório local do partido político. Repise-se, apenas a atuação dos membros do diretório - e não dos filiados em geral do partido, como dito - pode implicar a responsabilidade penal do diretório. Mesmo em relação ao candidato, se não for membro do diretório, sua conduta não poderá implicar a responsabilidade deste ente, pois ser representante é o critério normativo eleito como fundamental à imputação da responsabilidade ${ }^{52}$.

Logicamente, não será qualquer conduta das pessoas individuais que poderá acarretar a imputacão do fato delitivo à pessoa jurídica, sendo imprescíndivel que o membro ou os membros do diretório local participantes do processo de deliberação ou da execução do ato estivessem a

49. RAMAYANA, Marcos. Direito Eleitoral. Rio de Janeiro: Impetus, 2008. Pp.758-759

50. LUCON, Paulo Henrique dos Santos; VIGLIAR, José Marcelo Menezes. Código Eleitoral Interpretado. 2ed. Atlas, São Paulo: 2011. P. 402

51. GOMES, Suzana de Camargo. Ob. cit. P. 216

52. Diferentemente do que ocorre nos crimes ambientais, em que não há especificação acerca de quem deve perpetrar a conduta para fins de implicação da pessoa jurídica, desde que "a infração seja cometida por decisão de seu representante legal ou contratual, ou de seu órgão colegiado, no interesse ou benefício da sua entidade" (Art. 3०, Lei 99605/98). 
atuar de acordo com os padróes e objetivos do partido político, agindo de forma a cumprir com suas funções e atividades ordinárias dentro da agremiação com o desiderato de atingir determinados objetivos traçados expressa ou implicitamente no âmbito do ente moral ${ }^{53}$.

Quanto ao concurso, o magistrado deverá analisar se o diretório local do partido concorreu para a perpetração do crime apurado. Concurso, dentro do sistema dogmático adotado pelo Código Penal brasileiro, em suas disposições gerais, é gênero do qual são espécies a autoria (imediata, mediata, coautoria, colateral) e a participação. Autor é todo aquele - segundo a moderna doutrina solidificada por ROXIN no monumental Täterschaft und Taherrschaft no ano de 1963, a partir das importantes contribuições do finalismo, principalmente de HANS WELSEL - que tem o domínio do fato ${ }^{54}$, ou seja, é todo aquele que executa pessoalmente o delito, ou o faz por intermédio de entreposta pessoa (por coação, por erro, por instigação-autoria ${ }^{55}$ ou em virtude de aparatos organizados de poder ${ }^{56}$ ) ou o realiza em conjunto com outros individuos, numa imputação recíprocas das distintas contribuições ${ }^{57}$. $\mathrm{O}$ conceito de partícipe é dado por exclusão, i.é, partícipe é todo aquele que aporta para o delito um contributo material, mas não se adequa ao conceito de autor.

Não obstante haja entendimento de que a responsabilidade penal do diretório "pode ser imposta, mesmo não tendo havido o concurso direto de membros dos diretórios, bastando para tanto tenha havido a obtenção consciente de benefícios pelo partido político"s8, entendemos que tal não se dá, uma vez que a lei é clara na fixação dos requisitos, colocando-os, na hipótese aventada de forma cumulativa, a atuação por meio de qualquer de seus representantes e a consciência da obtenção do benefício. Se assim não fosse, estaríamos diante de verdadeira responsabilidade penal objetiva, onde sequer poderia haver imputada, por qualquer meio dogmático, à

53. STF - RE 548181 / PR Min. Rosa Weber.

54. "En la autoría mediata el dominio del hecho presupone que el acontecimiento global se presenta como obra de la voluntad directiva del hombre de atrás y que éste controla la acción del ejecutor por medio de su influência sobre él." JESCHECK, Hans-Heinrich. Ob. Cit. P. 715. Ensina Roxin que a Autoria Mediata ocorre quando "a) Es posible utilizar en la ejecución del plan delictivo un hombre que obra por error (...) b) ... una realización mediata del tipo reside en el uso de la fuerza.(...) c) alguien sirve a la ejecución de un plan de ejecución para una organización jerárquicamente organizada" a que este Autor chama de "dominio de la voluntad mediante un aparato de poder organizado" ROXIN, Claus. Problemas Actuales de las ciencias penales y la filosofía del derecho. Ediciones Pannedille: Buenos Aires, 1970, Pp. 62-63.

55. Figueiredo Dias. Direito Penal. Parte Geral. Tomo I. $2^{\circ}$ Edição. Questôes Fundamentais. A doutrina geral do crime. Coimbra Editora. 2007, pag. 799.

56. Para análise da teoria e das críticas à autoria por aparatos organizados de poder ver Kai Ambos. Dominio del hecho por dominio de voluntad en virtud de aparatos organizados de poder. Una valoración crítica y ulteriores aportaciones. in: Themis, $\mathrm{N}^{\circ} 37$, Lima, 1998.

57. "La terceira forma de domino del hecho corresponde a la coautoria, que yo he designado como "autoria funcional": en este caso varios correalizan la ejecución en distintos papeles (funciones) de tal forma que sus aportes al hecho tomados en sí, completan la total realización del tipo..." ROXIN, op. Cit. 65. Complementa PUIG: "Los coautores porque cometen el delito entre todos. Los coautores se reparten la realización del tipo de autoría. Como ninguno de ellos por si solo realiza completamnete es hecho, no puede considerarse a ninguno partícipe dem hecho de outro. (...) el principio de imputación reciproca de las distintas contribuiciones. Segin este principio, todo lo que haga cada un de los coautores es imputable (es extencible) a todos los demás. Sólo así puede considerarse a cada autor como autor de la totalidad. Para que esta imputación recíproca pueda tener lugar es preciso el mutuo acuerdo, que convierte en partes de un plan global unitário las distintas contribuiciones" ob. Cit. 400, 410.

58. GOMES, Suzana de Camargo, ob. Cit..., Pag 216. 
pessoa jurídica, por se constituir uma mera imputação de resultado, o que não se coaduna com o Direito Penal, apenas imaginável no Direito Civil, e em excepcionais hipóteses.

Não convencem os argumentos de que a responsabilidade penal da pessoa jurídica é consequência da responsabilidade penal da pessoa física, e desta sempre dependente, pois o sistema adotado pelo art. 336 do CE é o de que a pessoa jurídica deve responder por suas próprias ações e com base em sua própria culpabilidade. Não sendo imprescindível, assim, a análise prévia do comportamento do agente individual, devendo ser verificado diretamente o comportamento da pessoa coletiva. Neste sistema de responsabilização direta ou autorresponsabilidade, considera-se que pessoa física e pessoa jurídica atuam conjuntamente, mesmo que se lhes possam ser impostas responsabilizações separadas e independentes entre si. Aqui, a conduta da pessoa física é um feito de referência, que é levada a análise sob os critérios normativos de imputação a fim de se verificar se há ou não a responsabilizadade penal da pessoa juridica, com base em critérios normativos de imputação que permitem considerar a pessoa coletiva como autora culpável pelo fato e lhe impor uma pena, a partir da realização de uma conduta objetivamente violadora da norma penal levada a efeito pela pessoa individual. Há um elevado grau de independência entre as responsabilizações penais da pessoa física e jurídica, não havendo atribuição direta e necessária da pessoa jurídica se age a pessoa física delituosamente, bem como não há uma automática exclusão da pessoa coletiva se a pessoa física não é responsabilizada ${ }^{59}$.

Mesmo se se considerar a teoria da identificação ou do alter ego, chamado modelo vicarial - consistente na verificação de maneira indireta da responsabilidade penal da pessoa jurídica através do delito de uma pessoa física individualizada que pratique o delito no âmago do ente coletivo, podem ocorrer casos em que a pessoa jurídica é condenada isoladamente, sem a pessoa individual (por razóes substantivas ou processuais).

De outra parte, não há dúvidas que a sanção imposta é de natureza penal, uma vez que a restrição de direitos é modalidade de pena prevista na Constituição Federal e no próprio Código Penal ${ }^{60}$. A restrição de direitos pode se dar - como de fato se dá - sob a forma de interdição temporária de direitos. Assim é com a proibição do exercício de cargo, função ou atividade pública, ou de profissão, atividade ou ofício, por exemplo, previstas no art. 47 do CP.

A sanção deve ser adequada à natureza do ente a que se destina, neste caso, a suspensão de atividade é perfeitamente adequada à natureza coletiva do diretório do partido político - como o é a pena de multa, por exemplo - não se podendo cogitar, nesta hipótese, de pena privativa de liberdade ou proibição de frequentar determinados lugares, por absoluta inadequação à essência da pessoa jurídica. Por outro lado, a pena de interdição temporária de direitos deve ter ligação direta com a natureza do delito perpetrado, neste caso, há uma umbilical ligação entre os crimes descritos do art. 336 do CE e a suspensão da atividade eleitoral. Ademais, a pena de suspensão da atividade eleitoral tem um caráter predominantemente preventivo, pois visa a evitar a recorrência da desobediência às regras fundamentais das eleiçóes por meio de conduta penalmente ilícita pelo diretório local do partido político.

59. Neste sentido "a Constituiçâo Federal de 1988 (art. 225, §3º) permite a apenação da pessoa jurídica sem que, necessariamente, se atribua o mesmo fato delituoso à pessoa física, bastando que fique demonstrado que o ilícito decorreu de deliberaçóes ou atos cometidos por indivíduos ou órgãos vinculados à empresa, no exercício regular de suas atribuições internas à sociedade, enquanto comportamentos aceitos pela pessoa jurídica, concernentes à sua atuação social ordinária; e ainda que tal atuação tenha se realizado no interesse ou em benefício da entidade coletiva" STF - RE 548181 / PR Min. Rosa Weber.

60. "Art. 43. As penas restritivas de direitos são: (...) V -interdição temporária de direitos;" 
Acrescente-se, ainda, que a sanção penal prevista no parágrafo único do art. 336 do CE está revestido de superior técnica legislativa, no sentido de que tem em si uma moldura penal, que se move no intervalo do mínimo da pena - seis meses - e o máximo - 24 meses - com a qual o legislador divide com o juiz a atividade de fixação da resposta penal, deixando a este último a função de analisar o caso concreto e, levando em conta as circunstâncias do art. 59 do $\mathrm{CP}$, no que couber, e do próprio parágrafo único, no caso a reincidência, fixará a pena ${ }^{61}$.

A apuração da responsabilidade penal do diretório do partido político se dá por meio de um processo penal, com todas as garantias que lhe são inerentes, ou seja, deve ser a pessoa jurídica denunciada e os fatos que a ligam ao delito devem ser minunciosamente, na medida do possível, relatados na peça delatória. Assim, poderá o diretório pessoa jurídica se defender dos fatos imputados e das consequências jurídicas que decorrem dos mesmos. Exercitando o contraditório e a ampla defesa que a todos são assegurados, com as adaptaçóes que são necessárias à pessoa jurídica, podendo ser utilizados, subsidiariamente, os regramentos do processo civil pertinentes ao exercício dos direitos constitucionais do ente coletivo, bem como para se desincumbir de seus deveres processuais ${ }^{62}$.

\section{Conclusão}

1. A questáo da responsabilidade penal da pessoa jurídica avulta de importância no contexto atual, na medida em que se identifica o ente coletivo no vórtice da criminalidade de alta escala e de alta complexidade, nomeadamente nos crimes econômicos e ambientais, mas, também, nos crimes eleitorais.

2. Impõem-se a busca por uma nova dogmática penal e suas categorias de análise do delito, de forma a adequar-se a esta modalidade de delinquência, sem descurar-se do respeito aos princípios constitucionais penais erigidos tão duramente ao longo dos séculos e que asseguram uma limitação da intervenção do Estado nos direitos, liberdades e garantias.

3. O partido político, enquanto pessoa jurídica de direito privado, é passível de responsabilização penal, em vista dos critérios de imputação eleitos pelas disposições do art. 336 do Código Eleitoral, que guardaram relação de constitucionalidade com a Carta de 1946, sob cuja égide foi promulgada, bem como foi recepcionada pela Constituição Federal de 1988, por não lhe contrariar as disposições.

4. A hipótese prevista no art. 336 do CE se trata verdadeiramente de responsabilização penal da pessoa jurídica, porque a referida norma: a)está inserida em contexto (literal e tópico) puramente criminal; b)é expressa em se reportar à atuação da pessoa jurídica diretório local por intermédio de seus representantes num contexto delituoso; c)a responsabilidade é apurada em processo penal; d) a sanção é proferida em sentença com juízo de certeza (após a verificação do juiz, por livre convencimento motivado, na sentença); e) a suspensão da atividade eleitoral é modalidade de pena restritiva de direito, mais especificamente, interdição

61. Repartição de tarefas e dever de cooperação, jurídico-constitucionalmente vinculada, que existe entre o legislador e o julgador para a individualização e aplicação da pena. Figueiredo Dias. Op. Cit., 2005. P. 193

62. Sobre o tratamento processual da pessoa jurídica, ver GRINOVER, Ada Pellegrini. Aspectos processuais da responsabilidade penal da pessoa jurídica. Coleção Temas Atuais de Direito Criminal. Cood. Luiz Flávio Gomes. São Paulo. Editora RT. 1999. Pp. 46-50. 
temporária de direitos; e f) se trata de sanção com moldura penal, em que serão levadas em consideração as circunstância do art. 59 do CP e do parágrafo único do próprio art. 336 do CE.

5. Apenas a conduta dos membros do diretório local, especificamente falando, - e não dos filiados ao partido em geral, ou de outros diretórios, ou mesmo o candidato - pode implicar a responsabilidade penal do partido político, é a conduta do representante do diretório o critério normativo eleito como fundamental à imputação da responsabilidade criminal.

6. Para a imputaçãoo do fato delitivo à pessoa jurídica, se torna imprescíndivel que o membro ou os membros do diretório atuem com o desiderato de atingir determinados objetivos traçados expressa ou implicitamente no âmbito do partido, como forma de cumprir com suas funções e atividades ordinárias dentro da agremiação.

7. Não basta o benefício do partido político, este deve ser cumulado com a conduta de um dos representantes do diretório, sob pena de se ter uma odiosa responsabilidade penal objetiva, apenas vinculada ao resultado.

8. A existência de uma culpabilidade própria da pessoa jurídica, e a imputação da conduta do representante a esta, faz com que a apuração de sua responsabilidade se dê de forma independente da apuração da responsabilidade da pessoa individual, havendo uma acessoriedade mínima em relação ao fato ilícito-típico de referência perpetrado diretamente por esta.

9. A responsabilização penal individual efetiva do membro do diretório não é necessária, ou seja, para que haja a responsabilização penal do diretório local não é condição imprescindível que o representante também seja responsabilizado, uma vez que em relação a este podem existir circunstâncias que o retirem da esfera da punibilidade, com, por exemplo, a extinção pela morte do agente.

10. Quando da aplicação da pena de suspensão da atividade eleitoral ao diretório, deve o juiz levar em consideração, no que couber, as circunstâncias inscritas no art. 59 do CP, bem como a reincidência inscrita no parágrafo único do art. 336 do CE, a fim de realizar a individualização da pena e fixar o quantum de acordo com o caso em concreto, ou seja, a aplicação de uma pena justa.

11. O diretório do partido político, enquanto agente ativo do crime e pólo passivo na demanda processual penal, deve ter respeitados todos os direitos fundamentais inerentes à condição de réu, como o devido processo legal, contraditório e ampla defesa, inclusive devendo constar na denúncia todos as condutas que lhe são atribuídas, para que possa exercer sua defesa de forma eficiente.

12. $\mathrm{O}$ processo penal deve seguir com as adaptações que são necessárias à pessoa jurídica, utilizando, quando pertinente, os regramentos do processo civil, subsidiariamente, a fim de possibilitar o exercício dos direitos constitucionais do ente coletivo, bem como para que este possa se desincumbir de seus deveres processuais.

\section{Referências bibliográficas}

BACIGALUPO, Silvina. La Responsabilidad Penal de las Personas Jurídicas. Barcelona: Bosch, 1998. 
CARVALHO, António Crespo Simões de. A responsabilidade penal das pessoas colectivas. Texto dactilografado. Dissertação de licenciatura apresentada à Faculdade de Direito da Universidade de Coimbra, 1934.

COSTA, Faria. A Responsabilidade Jurídico-penal da Empresa e dos seus órgãos (ou uma Reflexão sobre a Alteridade nas Pessoas Colectivas, à Luz do Direito Penal). Revista Portuguesa de Ciência Criminal. Lisboa: Ano 2 (1992).

COSTA, Tito, Crimes Eleitorais e Processo Penal Eleitoral. Editora Juarez de Oliveira, São Paulo: 2002 .

DIAS, Jorge de Figueiredo. Direito Penal. Parte Geral. Tomo I. $2^{\circ}$ Edição. Questões Fundamentais. A doutrina geral do crime. Coimbra Editora. 200

DÍEZ, Carlos Gómez-Jara. El modelo constructivista de autorresponsabilidad penal empresarial. In Modelos de autorresponsabilidad penal empresarial propuestas contemporáneas. Madrid: 2006.

FRANCO, Affonso Arinos de Mello. Responsabilidade criminal das pessoas jurídicas. Rio de Janeiro. Gráfica Ypiranga, 1930.

GOMES, Suzana de Camargo. Crimes Eleitorais. 2a Edição. Editora: Revista dos Tribunais. São Paulo: 2006.

GRECO, Rogério. Curso de Direito penal: parte geral. V.1. 12. ed. rev. ampl. e atual. Impetus, Rio de Janeiro: 2010.

GRINOVER, Ada Pellegrini. Aspectos processuais da responsabilidade penal da pessoa jurídica. Coleção Temas Atuais de Direito Criminal. Cood. Luiz Flávio Gomes. São Paulo. Editora RT. 1999.

JESCHECK, Hans-Heinrich. Thomas Weigend. Tratado de Derecho Penal. Parte General. Tradución de Miguel Olmedo Cardenete. Quinta Edición. Comares Editorial. Corregida y Ampliada.

KELSEN, Hans. A Democracia. Ed. Martins Fontes. São Paulo: 2000.

LISZT, Franz von. Tratado de Direito Penal Allemão. Tradução da última edição e commentado por José Hygino Duarte Pereira, Tomo I, Rio de Janeiro: F. Briguiet \& C. Editores, 1899.

LUCON, Paulo Henrique dos Santos; VIGLIAR, José Marcelo Menezes. Código Eleitoral Interpretado. 2ed. Atlas, São Paulo: 2011.

MIRANDA RODRIGUES, Anabela. A determinação da medida da pena privativa de liberdade : os critérios da culpa e da prevenção. Coimbra: Coimbra Editora, 2014. 
NUCCI, Guilherme de Souza. Manual de Direito Penal: parte geral; parte especial. 4. ed. São Paulo: Editora RT, 2008.

PAULO, Vicente; ALEXANDRINO, Marcelo. Direito Constitucional Descomplicado, 7. Ed. Método. São Paulo: 2011.

PUIG, Santiago Mir. Derecho Penal. Parte General. 9a Edición. Barcelona: Editorial Reppertor, 2011.

PUIG, Santiago Mir. Sobre la responsabilidade penal de las personas juridicas. Luziada no 3, Lisboa: Universidade de Lisboa, 2005.

RAMAYANA, Marcos. Direito Eleitoral. Rio de Janeiro: Impetus, 2008.

ROXIN, Claus. Derecho Penal. Parte General, Tomo I. Fundamentos, La Estructura de la Teroria del Delito (Traducción y notas: Diego Manuel Luzón Peña, Miguel Diaz y Garcia Conlledo, Javier de Vicente Remesal). Civitas. 1997.

ROXIN, Claus. Problemas Actuales de las ciencias penales y la filosofía del derecho. Ediciones Pannedille: Buenos Aires, 1970.

SCHÜNEMANN, Bernd. Responsabilidad penal en el marco de la empresa. Dificultades relativas a la individualización de la imputación. Anuario de Derecho penal y Ciencias penales. VOL. LV. Madrid: 2002.

SCHÜNEMANN, Bernd. O Direito Penal é a Ultima Ratio da Proteção de Bens Jurídicos. Sobre os Limites Invioláveis do Direito Penal em um Estado de Direito Liberal. Revista Brasileira de Ciências Criminais. São Paulo, n.53, 2005.

SILVA, Jose Afonso da. Curso de Direito Constitucional Positivo. $25^{\circ}$ Ed. Maleiros Editora. São Paulo: 2005.

TEUBNER, Gunther. O direito como sistema autopoiético. Tradução e prefácio de José Engracia Antunes. Lisboa: Fundação Calouste Gulbenkian, 1993.

TIEDEMANN, Klaus. Responsabilidad penal de personas jurídicas y empresas en derecho comparado. Coleção Temas Atuais de Direito Criminal. Cood. Luiz Flávio Gomes. São Paulo. Editora RT. 1999.

TORRÃO, Fernando. Societas delinquere potest? : da responsabilidade individual e colectiva nos "crimes de empresa". Coimbra. Almedina. 2010.

ZAFFARONI, Eugenio Raúl. Alejandro Alagia; Alejandro Slokar. Derecho Penal. Parte General. Buenos Aires, Argentina. Segunda Edición. 2002. 
Recebido em: $14 / 03 / 2015$

Aceito em: 20/04/2015

\section{Como citar}

ROCHA, Jorge Bheron. A Responsabilidade Penal da Pessoa Jurídica no Código Eleitoral Brasileiro - O Artigo 336. Ballot. Rio de Janeiro: UERJ. Volume 1 Número 1 Junho 2015. pp. 139-158. Disponível em: [http:// www.e-publicacoes.uerj.br/index.php/ballot]

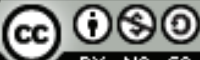

A Revista Ballot está licenciada sob uma licença Creative Commons Atribuição - Não Comercial - Compartilha Igual 3.0 Não Adaptada. 